\title{
The Transmediation of Ambivalence. \\ Violence and Music in Burgess's A Clockwork Orange and Kubrick's Film Adaptation
}

\begin{abstract}
This article explores the relationship between violence and art music in Anthony Burgess's $A$ Clockwork Orange and Stanley Kubrick's film adaptation. Instead of focusing on differences between novel and film, the intermedial perspective of this study is on underlying similarities beyond the different media characteristics of film and literature. Both the novel and the film exploit how the somatic impact of music creates a fundamentally ambiguous relationship between violence and music. Musical choices in the novel and the film at first glance appear incongruous. However, an intermedial approach reveals a connection between the textual and audiovisual ambiguity, unknown fictive music described in the novel and the wellknown music played in the film, defamiliarised lyrics and distorted sound. Thus, the novel and the film not only present the inherent violent potential of music; both works also exploit the attitudinal ambivalence created by the contiguity of music and violence. Music in violent contexts, which at first appears to distance us from violence seen, in fact pushes us towards the experience of felt ambivalence that undermines the order of things.
\end{abstract}

Keywords: Music, Violence, A Clockwork Orange, Intermediality, Ambivalence.

\section{Introduction}

In both film and literature, art music frequently appears in violent contexts. Helicopters attack to the sound of Wagner's "Ride of the Valkyries" in Francis Ford Coppola's Apocalypse Now (1979); Hannibal Lecter listens to Bach's Goldberg variations in Jonathan Demme's The Silence of the Lambs (1991); and an SS-officer plays Bach in the midst

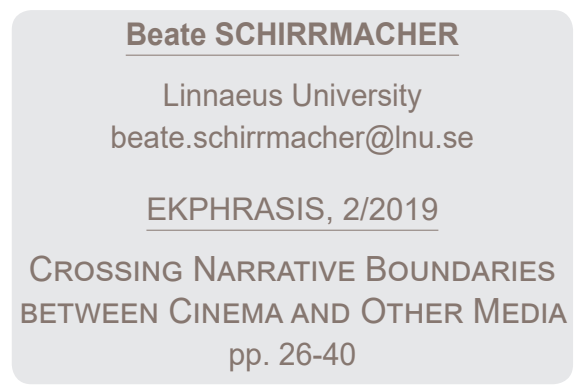

DOI:10.24193/ekphrasis.22.2

Published First Online: 2019/11/27 
of the brutal evacuation of the Jewish ghetto in Steven Spielberg's Schindler's List (1993). The violent power of music already is a recurrent topos in Romantic literature (Gess). Representations of music appear in literary texts approaching the Holocaust, such as Paul Celan's "The Death Fugue" (1948) or Günter Grass's The Tin Drum (1959) (Schirrmacher Musik in der Prosa 120-44). In Anthony Burgess's novel A Clockwork Orange (1962) the hooligan Alex loves ultra-violence and Beethoven.

These examples not only highlight the role of music in war and conflict throughout history (Goodman). Aesthetically, they also establish a relationship between violence and music which often is left unexplored or simply referred to as "alienating and offputting" (McQuiston 109), "a most disturbing feature" (Phillips 86), which leaves the viewer/reader to speculate about its reasons (Gengaro 33).

Although the contiguity of music and violence appears to be a transmedial motif, the motif is perceived differently in film and literature. In film, the montage of violent images and the sound of art music compels the audience to experience the contrast between order and disorder, aesthetical and ethical reactions. In literature, however, violent metaphors describing music or musical metaphors describing violence are not necessarily perceived as disruptive. Thus, Burgess's A Clockwork Orange was appreciated for its use of language. Kubrick's film, though a euphemistic adaptation of the novel's violence, roused an uproar. The novel did not. Although the connection between music and violence may not be as conspicuous in literature, the explicit textual connection may be used to shed light on the role of music in violent film scenes as well.

This study explores and compares how Anthony Burgess's novel A Clockwork Orange and Stanley Kubrick's film adaptation connect music and violence. The fact that violence is seen on the screen and music is heard in the soundtrack calls for substantial changes in Kubrick's film when compared to Burgess's novel. These changes have, on the one hand, been seen as proof of Kubrick's creativity; on the other hand, they have been understood as fundamentally skewing the musical and historical argument of the novel (Code, Rabinowitz).

The following analysis revisits some of the apparent differences between the novel and the film but does not stop at pointing out obvious discrepancies. Instead, this study focuses the underlying similarities that novel and film share by drawing on Lars Elleström's argument that "intermediality must be understood as a bridge between medial differences that is founded on medial similarities" ("Modalities of Media" 12). As materiality and mediality always forms what is communicated, all kind of media transformations involve changes. The question is how the changes contribute to reconstruct what is previously communicated in another medium. This process of reconstruction through transformation Elleström calls transmediation (Media transformation 14). Thus, in the following, it will be asked how the close relationship between music and violence, previously constructed in text on a book page is reconstructed, transmediated by moving images and sound. Thus, the textual 
ambiguity of the novel and the audiovisual ambiguity of the film, the (unknown) fictive music in the text and the (well-known) popularized music in the soundtrack can be explored to understand the ways both the novel and the film exploit the ambiguity of music and violence to create the experience of felt ambivalence.

\section{Music, violence or ambiguity?}

Ambiguity is a recurring topic in discussions of $A$ Clockwork Orange, both novel and film. The representations of modernity, gender (deRiosa) and the role of the artificial slang of nadsat (Goh) are all complex. However, the fundamentally ambiguous relationship between music and violence and notions of ambivalence they evoke together has been left curiously unexplored. To the protagonist, the teenage hooligan Alex, they are inseparable like two sides of a coin. Both violence and art music give him similar experiences of pleasure. As a consequence, after his reconditioning in prison, both cause him pain and nausea. This close relationship between music and violence is never fully explained.

Literary studies often tend to avoid this jarring connection by focusing either on the novel's subject - the ethical questions of violence and free will - or on the novel's form - its musicalized structure and intriguing language use. Thus, Todd Davis and Kenneth Womack discuss the question of free will and violence without giving much attention to Alex's love for music (25). Similarly, when Paul Phillips analyses the novel's structural repetition, modelled on the sonata form (88-9), Alex's violence remains "a most disturbing feature" (Phillips 86), leaving the connection unreconciled. When Robbie Goh, in "'Clockwork' Language Reconsidered", explores the linguistic features of the teenage slang nadsat, the musical qualities and the linguistic violence of nadsat remain unconnected to the role of music and violence in the plot. Especially when the novel is described as a "linguistic symphony" (Sorlin 56) or presented as an idealization of art music (Schabram 148), these interpretations do not take into account Alex's disturbing love for both art music and extreme violence.

Alex's musical taste cannot be explained only with Burgess's contempt for modern popular music (Morrison in the "Introduction" to A Clockwork Orange, xiii). In a way, Alex confronts the reader with the same disturbing question that beset postwar Europe when confronted with the problem of music-loving SS-men. As Peter Rabinowitz points out, the novel "probes the tie between classical German tradition and masculine violence" (120). Indeed, Burgess is not the only one to connect the music of Beethoven with violent emotions. Even in Leo Tolstoy's Kreutzer Sonata, the music of Beethoven incites murder; and in her provocative analysis of Beethoven's Ninth Symphony, musicologist Susan McClary draws attention to the way in which the music of Beethoven "quite regularly push[es] mechanisms of frustration to the limit, such that desire [...] frequently culminates [...] in explosive violence" (127). However, hearing Beethoven as violent is less a question of a moral judgement on music than a heightened experience of ambivalence (Rabinowitz 121). Peter Höying 
finds it "irritating not knowing whether Beethoven's Ninth has the power to be an instrument of therapy, of torture - or actually both" (172-73).

Even if the discussion of music in $(A)$ Clockwork Orange easily centers on the music of Beethoven, this music has to be considered in the context of other forms and traditions of music in both novel and film. Rabinowitz demonstrates the importance of the fictive pieces of music in the novel. Recent studies of the film's soundtrack (Gengaro, Code), suggest the music of Purcell and Rossini is at least as important as Beethoven's Ninth Symphony (Code 345).

In studies on Kubrick's film adaptation, the simultaneous presence of music and violence has been more explicitly addressed. However, their ambiguous relationship has mainly been discussed as something added in the adaptation. As Claudia Gorbman has shown, Kubrick's characteristic use of pre-scored music generally creates detachment yet, at the same time, is perceived as emotionally appropriate (4). Thus layers of complexity in the relationship between music and violence added by the soundtrack of the film have mainly been discussed as features that "reframe" (Code 340) or "distort, even invert the aesthetic arguments" (Rabinowitz 114) of the novel.

Less effort has been made to understand how the apparent changes can be seen as a transmediation of the novel's intrinsic relationship between music and violence in plot and structure. And although the role of art music in violent contexts is appreciated as highly ambiguous in the film, it is still perceived as strangely arbitrary, an "illusion of conditioning" (McQuiston 121), or a "symbolic representation of Alex's free will" (Gengaro 33). Gengaro points out that it remains open for speculation "how [art music] came to be so important and so intertwined with [Alex's] violent impulses." (33) Any attempts to find a causal explanation within the plot for the contiguity of music and violence do not lead to further understandings.

When high-valued art music appears in a context of negatively connoted violence and destruction, positive and negative evaluations are simultaneously present and may produce attitudinal ambivalence. Ambivalence, "the simultaneous existence of positive and negative evaluations of an attitude object" (Conner and Sparks 39), the "possibility of assigning an object of an event to more than one category" (Baumann 1) leads to cognitive dissonance and psychological discomfort. We are always surrounded by ambiguity although it is not always felt as ambivalence. We perceive attitudinal ambivalence especially if conflicting evaluations are simultaneously accessible or if there is a high preference for consistency (McGregor et al. 158), for instance if we are confronted with ambiguity in a context in which we feel it important to get things straight. This is the case, when music and violence appear together and both aesthetical and ethical evaluations apply.

Thus, A Clockwork Orange does not enable the reader to evaluate music and/ or violence as 'good' or 'bad'. Instead, as I argued in "Ambivalenz verspüren," the novel exploits the cognitive dissonance that arises out of the contiguity of music and 
violence. Seen from this perspective, the sometimes contradictory representations of music and violence in the novel and the film can be understood as different transmediations of the experience of ambivalence created within the media specificity of film and literature.

\section{The somatic impact of music and the ambivalence of music and of violence}

How does A Clockwork Orange draw the attention towards the potential ambivalence of music and of violence? Some clues to answering this question can be found when looking at the textual representation of music in the novel.

Usually, the representation of music in literature involves descriptions of sound and listening. This "acoustical foregrounding" (Wolf 75) is surprisingly absent in A Clockwork Orange. When Alex listens to music, he describes a bodily experience that hits him in the gut. Music is a "visceral pleasure" (Gengaro 46) that resonates in his body: "[ $t$ ]he timps rolling through my guts and out again crunched like candy thunder" (Burgess 33). Music arouses Alex sexually and it is hard to tell whether he listens to music, or has an orgasm, or both:

When the music $[. .$.$] rose to the top of its big highest tower, then, lying$ there on my bed with my glazzies [eyes] tight shut and rookers [arms] behind my gulliver [head], I broke and spattered and cried aaaaaaah with the bliss of it. (Burgess 27)

Even the film shows music as a bodily experience close to sexual pleasure. In the corresponding scene to the quoted passage, Alex appears to be masturbating while listening to the second movement of Beethoven's Ninth. As always when listening to music, he does not display a culturally coded face of musical rapture; his distorted, "demented" (Kearns 127) facial expression indicates intense bodily sensation. Accordingly, when music causes him nauseous pain, it provokes grotesque belching sounds.

The bodily reactions to music are not a coincidence. Unlike other art forms, sound waves from music literally touch the body. As with sex, the trespassing of physical borders can give sensual pleasure yet it is perceived as an assault when in lack of control. Volume, recognition and personal control decide whether sounds are perceived as noise, as music or as acoustical violence. "Any music," Johnson and Cloonan point out, "can be employed to engender pain" (22).

Thus, the somatic impact of sound connects the music to the experience of violence and indicates why music is a suitable medium for domination. As Alex's description of music suggests a physical assault, the readers become aware of the potential ambivalence of music and (violent) noise. Taken together, music and violence become "undecidable" in Derrida's sense of the word, they undermine the order of binary oppositions in general (Baumann 55-6). Thus the contiguity of music and violence 
even draws attention to the potential ambiguity between order and violence that emerges each time when concepts like power, order or violence are approached (see e.g. Benjamin, Arendt, Žižek).

In reflections on this kind of ethical and aesthetic ambiguity, one often finds attempts to decide which 'side' the novel or the film takes on the issues of violence, free will, modernity. However, binaries do not provide consistent answers but remain unstable. As both the novel and the film represent music as somatic experience, they highlight the connection of seemingly oppositional ideas and seemingly distinct experiences. Music is not simply criticized, nor is violence simply aestheticized; instead, taken together, they create felt ambivalence, the discomfort of cognitive dissonance that undermines the order of things.

\section{Textual, Visual and Acoustical Ambiguity}

The undermining of binaries is transmediated differently in the novel and in the film. The novel is written completely in the dazzling polyphony of Alex's Russianbased slang nadsat. Thanks to context and repetition, even non-Slavic speakers understand nadsat, a kind of meaning-making similar to musical understanding. Reading nadsat conveys a polyphonic experience, a constant play with sounds as language material (Goh 267), which at times forms contrapuntal relationships of contradicting yet interrelated interpretations. For example, Alex's use of his favorite positive intensifier "horrorshow" is phonetically similar to the Russian 'khorosho,' good, while the English spelling suggests the very opposite.

The constant semantic ambiguity of nadsat that "evokes sensations, rather than things" (McQueen 232) weakens the relationship between words and meanings and "masks the violence in unfamiliar words" (Rabinowitz 113). Burgess himself pointed out that "to tolchok a chelloveck in the kishkas does not sound as bad as booting a man in then the guts" (Burgess, Clockwork: A Play, viii). It spares the reader the "gut reaction" (Gengaro 46) to what is actually referred to. Thus, Goh explains, nadsat draws the reader's attention to linguistic violence (272), using the manipulative potential of creative language.

In the film, the passages of Alex's voice-over narration in nadsat cannot convey the same extent of polyphonic defamiliarization that happens when reading the novel. The playful and destabilizing ambiguity of nadsat is paralleled in the uncountable visual mirrorings of spaces, characters, forms, colours, appearing and disappearing props. The disturbing ambivalence of seeing and voyeurism, visual pleasure and visual assault (McQueen 234-37) connects to the linguistic violence of nadsat. The veiling aspect of nadsat, however, can also be traced in the way Kubrick employs the over-familiar music of Rossini's overtures (Gengaro 46), music nearly everybody knows even when not knowing the composer's name.

In the novel, the music of Beethoven is specifically connected with Alex's violent outbursts. In corresponding scenes in the film, such as the fight with Billy's gang 
and Alex's fight with his own gang, the audience hears the overture to Rossini's The Thieving Magpie instead. This musical choice contradicts Alex's love for AustroGerman music in the novel. Rossini's music appears to "wrap up the violence in familiar scores," Rabinowitz argues, which "could serve to distance us from it" (113).

However, what would be a 'faithful' adaptation of these scenes? In the text, the name of Beethoven as representative in art music as generally high-valued collides with affective negative responses towards Alex's sexual and violent excesses. However, hearing Beethoven as soundtrack to violent acts might highlight aspects that the music of Beethoven shares with the experience of violence.

Although detached from what is shown on screen, the overly familiar sounds of Rossini do not necessarily result in distancing the audience. Perceived as anempathetic, the apparent incongruousness serves as an indirect invitation to interpret the contrapuntal relationship between image and sound (Chion 124). The effect of the popularized overture music in the audiovisual context of the film is thus similar to the effect of unfamiliar sounds of nadsat in the novel.

We can trace this development from initial detachment to ambivalent involvement in the way Rossini's music interacts with violent noise in the fight with Billy's gang. To begin with, the overture of The Thieving Magpie is part of an overall aesthetic framing of the scene: Alex and his gang meet their rivals in an abandoned theatre, Billy's gang is on stage, on their way to rape a woman, and the fight that follows is stylized and choreographed. However, the frame of familiar music does not fully "neutralize the violence" (Rabinowitz 113), nor does it only allow us to see "the images on-screen dance-like" (Gengaro 46).

The movement of the fighters and the rhythm remains mostly unsynched, yet we can sense a merging, a blending of the percussion with the violent noise, the crashing of furniture and the shattering of glass. The percussion does not substitute for noise, nor are the percussion and noise perfectly synchronized. Instead, shattering glass and cymbals, snare drums and the crashing of furniture follow immediately upon each other. The division between music and noise becomes ambiguous, and the two are difficult to tell apart, especially when, at the end of the scene, hovering intervals in the violins blend into the interval of the approaching police sirens. The same blend of violins and sirens is heard when the police approach the house of the cat lady. This acoustic ambiguity deliberately creates attitudinal ambivalence as it blurs the border between art music, noise of destruction (shattering and crashing) and sounds connected to violence (police sirens). Kubrick uses the music of Rossini not just as a buffer; he employs it in a way that lets viewers experience the ambiguous line between musical sound and violent noise.

The film audience is made aware of other forms of attitudinal ambivalence when Alex listens to Beethoven's Ninth, such as when Alex returns home and listens to the second movement on an audio tape (0:18:300:19:47). To the sound of Beethoven, we first see details from Alex's room, the window blind with Beethoven's portrait moving 
in the breeze, the pet snake on the branch moving in front of painted woman's legs, the sculpture of a chorus line of naked Jesuses, followed by imagery of a bride falling to her death, Alex as a vampire with blooded fangs, the explosion of a volcano and cavemen buried under falling rocks, as well as various close-ups of the dancing Jesus sculptures.

In this scene as elsewhere in the film, Beethoven's Ninth replaces the description of fictive music in the novel. Thus, research has mainly tried to isolate the meaning that is added by setting Beethoven's music to parodic imagery of sexuality "juxtaposed with violence" (Höying 163), of "amoral power" (Gengaro 45), or simply of "B-movie horror and disaster" (Code 347). Moreover, the shots from Alex's room and the imagery that follows all present different (unexpected) motion of supposedly inert bodies: the portrait of Beethoven (with a resemblance to Mr Alexander) moving in the breeze, the living snake in front of a painted body, the figure of Christ multiplicated and dancing. Even in the subsequent imagery, the bride falling to her death, the undead vampire, the volcanic eruptions and the rock avalanches, movement is not a sign of life but of death and lethal threat. When the visual rhythm starts to align to the musical rhythm, the cutting of the film becomes violent, too, as it literally cuts the body of Christ into pieces. Accordingly, the passage provokes attitudinal ambivalence towards the very building blocks of film, the movement of (inert) images, the inherent violence of the cutting and the editing.

The textual ambiguity of nadsat is transmediated in different forms in the blends of noise and music, in the visual mirrorings and even in the images that self-reflexively highlight the violent aspects of the audiovisual medium of film. Together, they are able to evoke all-pervasive visual uncertainty that constantly evokes contrasting values and attitudinal ambivalence which is similar to nadsat narration in the novel.

\section{Involving the Audience: Unknown and Well-known Music}

As already indicated, the use of familiar music in the film soundtrack can be understood as a paradoxical means of involving the audience. The music provides distance to the violence on the screen, and thus the music prevents the audience from distancing themselves from the protagonist Alex. This anemphathetic use of wellknown music in the film has some parallels in the role of fictive music in the text. When Alex in the novel describes the fictive violin solo from a sonata by Geoffrey Plautus as a "bird of like rarest spun heaven metal, or like silvery wine in a spaceship, gravity all nonsense now" (39), his poetic descriptions present Alex as sensitive lover of high valued art music who cannot be "all bad" (Phillips 84). Moreover, Rabinowitz demonstrates how Alex's descriptions "moderate our antipathy to Alex's violence" (110) even rhetorically. We have no independent access to the pieces Alex describes; we have to accept and trust his (musical) judgement. Thus, we not only adopt his point of view; we even cooperate by contributing suitable auditory imagery of 'wonderful' music while reading. The unknown sounds of fictive music trap the reader into Alex's 
perspective, structurally preventing the reader from keeping a critical distance.

The well-known music of the film and the descriptions of unknown music in the novel may appear contradictory at first glance. Yet, in a way, they both result in the involuntary involvement of the audience. The familiar sound track in the film prevents critical distance by offering detachment. The descriptions of unknown music make the reader want to be as close to Alex's as possible, "to be where he is and to hear what he hears" (Rabinowitz 110). Thus, fictive music draws the reader headfirst into Alex's universe, similar to Alex's famous initial seductive gaze in the film.

In the film, when Alex performs "Singing in the Rain," we meet yet another way of creating attitudinal ambivalence. As a result of the actor Malcom McDowell's spontaneous decision, the song is not in line with Alex's musical taste in the novel (Rabinowitz 123). However, the musical song in the middle of a rape scene opens up for a conflict with our auditory memory of the musical. Alex's jump on the table mirrors Gene Kelley's iconic jump on the lamp post, and the sounds of kicks and screams replace the elegant tap-dancing. In the absence of orchestration, violent noise replaces the expected sound of familiar music in the auditory imagery. The scene both mimics and "mocks" the famous musical scene, and, as Sobchak puts it, "the violence and rape is done to the song" as well (215).

Alex's disturbing a capella performance also connects to music heard in the subsequent scene back in the Korova Milk Bar. In the novel, Alex hears a woman sing a short phrase from a fictive opera of Friedrich Gitterfenster with the parodic title Das Bettzeng ('The Bedclothes'). To Alex in the novel, the music sounds "as if some great bird had flown into the milk bar, and I felt all the little malenky hairs on my plot stand endwise" (27) and the reader is once again ready to contribute with suitable auditory imagery of 'wonderful' music, regardless of the fact that Alex maybe only adores this passage because of the operatic mix of sex, violence and music, as the heroine sings "when she's snuffing it with her throat cut" (27). In the corresponding film scene, a woman surrounded by men sings a capella the first two lines of the "Ode to Joy." Not only imaging but actually hearing the woman's improvised a capella performance appears risky, it opens up for contradicting Alex, for questioning his judgment. While a reader is not likely to contradict a textual description of a fictive piece of music, the film audience hearing the piece music described could. What if we do not think what we hear is similar to a "great bird that has flown into the milk bar?" In the film, the alignment with Alex is deliberately disturbed, especially as the single a capella voice mirrors Alex's "Singing in the Rain" performance and brings forth the female body, still vulnerable after the rape of Mr. Alexander's wife in the previous scene.

\section{The sound of the lyrics and distorted sounds}

In the novel, Alex says he is especially fond of the fourth movement of Beethoven's Ninth, with the choral finale. When the woman sings in the Korova Milk Bar, this is the only time we hear the most famous passage of the symphony in the film, although 
it is not performed by a choir with full orchestra nor in the futurizing sound of Wendy Carlos's Moog synthesizer, but by a single a capella female voice. In the film, the energetic rhythms of the second movement are highlighted and used to illustrate both the pleasure of listening to music, when it is suggested that Alex is masturbating to Beethoven, and the pain, while listening when he is tortured by his former victim Mr. Alexander. From the fourth movement, we hear mainly the military rhythmicized alla marcia passage and a short section from the fugato finale at the end of the film when Alex's ability to hear music has been restored.

Alex's fondness of "Ludwig van" and his "Glorious Ninth" has been extensively discussed concerning the inherent violence of Beethoven's music and the AustroGerman tradition in general (Rabinowitz), which may collide with idealized image of art music as symbol for civilized high culture (see McQuiston). This hybrid symphony is an ambiguous piece of music in itself, transgressing the boundaries of the symphony as an instrumental genre, using lyrics that celebrate joy with violent undertones (Höying 166-67). However, an intermedial perspective reveals yet another reason for the choice of this particular piece of music. Contrary to other famous symphonies, the Ninth can be easily and persistently evoked in a text by quoting text, more precisely the lyrics of the "Ode to Joy".

In fact, one reason for the focus on Beethoven in critical discussions of novel and film alike might also be found in the way the symphony is represented. In the novel, the lyrics are quoted in a way that are likely to provoke sticky music or involuntary musical imagery (Liikkanen 218). Like a melody of a song may evoke the absent lyrics and become what Lawrence Kramer calls speaking melody, the sound of the words in these lyrics activates the auditory imagery of the melody. The words 'We will rock you' may evoke some auditory imagery of the famous Queen song, for example. In particular, fragments and slight distortions of lyrics not only activate the musical memory to correct and complete, but also provoke involuntary musical imagery, continue and repeat fragments of sticky music in the mind (Liikkanen 217). The novel exploits this shortcut, and the lyrics are quoted in a way that tends to make the Ninth Symphony much more present than can be seen in the text, such as when Alex takes two ten-year-old girls up to his room and plays the choral finale on his record player:

[a]nd then the male human goloss [voice] coming in and telling them all to be joyful, and then the lovely blissful tune all about Joy being a glorious spark like of heaven, and then I felt the old tiger leap in me and then I leapt on these two young ptitsas [girls]. This time they thought nothing funny and stopped creeching with high mirth, and had to submit to the strange and weird desires of Alexander the Large (Burgess Clockwork, 47).

Immediately before Alex rapes the girls to the sound of the choral finale, he quotes fragments of the famous lyrics. Once activated, the auditory imagery of the Ninth Symphony can continue to spin in the reader's head even if Alex literally jumps into 
the rape. Fragments of the "Ode to Joy" are defamiliarised as they are translated into English into the novel but may connect to the original by keeping the meter ("I Embrace Ye O Ye Millions", 48) or violent rhyming words "Boy thou uproarious shark of heaven" (74). The fragmentary quoting of the Ninth is prone to evoke involuntary musical imagery throughout the novel and suggests that this symphony is much more present in the reading experience than in the actual text.

Involuntary musical imagery forms a virtual soundtrack of earworm quality that keeps the reader involved in passages they would like to keep a distance from: the rape of the girls and the brutal kicking (and even killing) of a fellow prisoner (Schirrmacher, "Sounding Words," forthcoming). Usually, the virtual soundscape that unfolds while reading is as inconspicuous as the soundtrack in a classic Hollywood studio film. However, when the sound that invokes involuntary musical imagery collides with a violent plot, readers may become aware of its involuntariness. They might perceive this soundtrack as anempathetic and yet be unable to turn it off. Hearing Beethoven's Ninth while watching Alex's violent outburst is rather the opposite of anempathetic, which Chion defines as unrelated to the emotional state of the characters in the film. And with "Ode to Joy" stuck in their heads, readers hear Alex's state of mind, involuntary tricked into contributing to a soundtrack according to Alex's violent impulses.

The novel's efforts to evoke the involuntary musical imagery of the Ninth by quoting distorted fragments of the "Ode to Joy" may help to explain why the film appears to avoid the most famous lyrics of the choral finale, apart from the a capella version in the Korova Milk Bar. Instead the audience hears passages less familiar, reminding them of the most famous section. When Alex visits the record store and we hear the melody played in a punctuated marching rhythm in the futuristic sound of the Moog synthesizer, it might even take some time to recognize Beethoven's Ninth. Considering the way distorted versions of famous lyrics in the novel can activate the reader's auditory memory, something similar might occur during the synthetised music in the film: the electronic alla marcia variation vaguely suggests and may evoke the memory of the more familiar passages.

In the conditioning and torture scenes, the synthesised sounds have been explained as expressions of how music has been distorted for Alex or from Alex's point of view. The only undistorted passage from the choral finale with the lyrics included is heard at the very end of the film, undistorted and with full choir and orchestra, when Alex is able to listen to music again. Together with a scene of consensual sex, the undistorted sound supports Code's suggestion which is based on the visuals: not only in the novel's last chapter, when Alex, some years older, voluntarily leaves ultraviolence, but even at the very end of the film, Alex is cured of his aggressive approach to music.

The lyrics of the Ninth that echo in the novel and the distorted sound of the synthesized versions in the film, with a focus on instruments passages both represent 
Beethoven's Ninth in a way that activates the auditory memory of the audience. The symphony appears to have a virtual presence that surpasses its actual presence in the text and the soundtrack, nesting itself as sticky music in the auditory memory of the audience.

\section{Conclusion}

The ambiguous relationship between music and violence that arises when the somatic experience of music is highlighted is exploited differently in the novel and the film of (A) Clockwork Orange. However, the examples discussed above demonstrate that the different approaches partly depend on the media characteristics of film and literature. Thus, different approaches to music are related, as they create similar kinds of attitudinal ambivalence. Textual polyphony and visual mirroring, well-known and unknown music, instrumental and choral passages of music, either distorted or only slightly manipulated, all work in similar ways towards an uncertainty in the relationship between music and (the noise of) violent destruction, between aesthetic order and violent assault, between experiences of pleasure and manipulation.

In all these cases, music is employed to prevent the audience from distancing themselves from the violence shown or described. Both the novel and the film compel the audience not only to see with but also to hear with the violent protagonist; both use music to keep the audience trapped in Alex's perspective. In the novel, the textual ambiguity of nadsat exploits the manipulative potential of language. Readers are conditioned, manipulated into accepting (or at least not reacting instinctively) to violence when experienced via the intriguing lens of nadsat. The all-pervasive linguistic ambiguity of nadsat is echoed in the visual ambiguity of the film, which is both intriguing and disturbing, visual pleasure and visual assault, highlighting the fine line between seeing and voyeurism.

Creating ambivalence is about putting together things we perceive as incongruous. Thus, the choices of music in the novel and the film that on first glance appear incongruous reveal connections when examined more closely. The fact that even the song "Singing in the Rain" can be played as a counterpoint to "Ode to Joy", as Burgess once demonstrated (Phillips 145), beautifully illustrates the intermedial position of this article, the perspective of the underlying similarities of these perceived differences. The cognitive dissonance that novel and film are able to evoke includes even other ambiguities of gender, time and other elements. Thus, the point of this investigation cannot be to decide whether the novel or the film primarily deal with social, aesthetical, ethical or gender questions. The point is to experience the destabilizing experience of uncertainty that is not to be solved.

The contiguity of music and violence plays an important role in the construction of a narrative that defies any stable pattern of explanation. The somatic experience of music is intrinsically connected to the experience of violence, though we usually do not think about music and violence in that way. Music, which at certain times during 
the film and novel appears to distance us from violence, also makes us swallow the bait, engaging with a plot that fundamentally deals with the difficulties we experience when our order of things does not correspond to the state of the world.

Why does art music tend to reappear in violent contexts? Both the novel and the film of $(A)$ Clockwork Orange make us uncomfortably aware of the dominating potential of music. At the same time, the novel and the film not only deal with the inherent violent potential of music (and of language, and of visual art, and of cinema). Additionally, they exploit the ambiguous relationship between music and violence to communicate the complexity of existence. Both performatively demonstrate how (individual) freedom and (social) constraint always are intrinsically linked; one cannot exist without the other. Music in violent contexts, which at first appears to distance us from violence seen, actually pushes us towards the experience of ambivalence. We experience the discomfort of our own urge to get things straight.

\section{Works Cited}

Arendt, Hannah. On Violence. Harcourt, 1970.

Baumann, Zygmunt. Modernity and Ambivalence. Polity Press, 2007.

Benjamin, Walter. "Zur Kritik der Gewalt." Walter Benjamin. Gesammelte Schriften, vol.

II.1. Edited by Hermann Schweppenhäuser and Rolf Tiedemann, Suhrkamp, 1999, pp. 179-204.

Burgess, Anthony. A Clockwork Orange. Heinemann, 1962.

. A Clockwork Orange: A Play with Music Based on His Novella of the Same Name. Hutchinson, 1987.

Chion, Michel. Audio-vision: Sound on Screen. Translated and edited by Claudia Gorbman, Columbia University Press, 2019.

Code, David J. "Don Juan in Nadsat: Kubrick's Music for A Clockwork Orange." Journal of the Royal Musical Association, vol. 139, no. 2, 2014, pp. 339-86.

Conner Mark and Paul Sparks. "Ambivalence and Attitudes." European Review of Social Psychology, vol. 12, no. 1, 2002, pp. 37-70, doi: 10.1080/14792772143000012.

DeRosia, Margaret. "An Erotics of Violence: Masculinity and (Homo) Sexuality in Stanley Kubrick's A Clockwork Orange." Stanley Kubrick's A Clockwork Orange. Edited by Stuart Y. McDougal. Cambridge University Press, 2003, pp. 61-84.

Davis, Todd and Kenneth Womack. "'O My Brothers': Reading the Anti-Ethics of the PseudoFamily in Anthony Burgess's 'A Clockwork Orange.'” College Literature, vol. 29, no. 2, 2002, pp. 19-36.

Elleström, Lars. Media Transformation. The Transfer of Media Characteristics among Media. Palgrave Macmillan, 2014.

. "The Modalities of Media: A Model for Understanding Intermedial Relations." Media Borders, Multimodality and Intermediality. Edited by Lars Elleström. Palgrave Macmillan, 2010, pp. 11-48. 
Gengaro, Christine Lee. Listening to Stanley Kubrick the Music in His Films. Scarecrow, 2013. Gess, Nicola. Gewalt der Musik: Literatur und Musikkritik um 1800. Rombach, 2006.

Goh, Robbie B. H. "'Clockwork' Language Reconsidered: Iconicity and Narrative in Anthony Burgess's A Clockwork Orange." Journal of Narrative Theory, vol. 30, no. 2, 2000, pp. 263-80.

Goodman, Steve. Sonic Warfare Sound, Affect, and the Ecology of Fear. MIT Press, 2010.

Gorbman, Claudia. "Ears Wide Open. Kubrick's Music.” Changing Tunes. The Use of PreExisting Music in Film. Edited by Phil Powrie and Robynn Stilwell. Ashgate, 2005, pp. 3-18.

Höying, Peter. "Ambiguities of Violence in Beethoven's Ninth through the Eyes of Stanley Kubricks's A Clockwork Orange". The German Quarterly, vol. 84, no. 2, 2011, pp. 159-76.

Johnson, Bruce and Martin Cloonan. Dark Side of the Tune. Popular Music and Violence. Routledge, 2009.

Kearns, Juli. "A Clockwork Orange Analysis." Idyllopus press, unginated. http://idyllopus press.com/idyllopus/film/co_one.htm. Accessed 12 Nov. 2019.

Kramer, Lawrence. "Speaking Melody, Melodic Speech." Word and Music Studies: Essays on Music and the Spoken Word and on Surveying the Field. Edited by Suzanne M. Lodato and David Francis Urrows, Rodopi, 2005, pp. 127-43.

Liikkanen, Lassi A. "Inducing Involuntary Musical Imagery: An Experimental Study." Musicae Scientiae, vol. 16, no. 2, 2012, pp. 217-34.

McClary, Susan. Feminine Endings. Music, Gender and Sexuality. University of Minnesota Press, 1991.

McGregor, Ian, Ian R. Newby-Clark and Mark P. Zanna. “Thinking and Caring About Cognitive Inconsistency: When and for Whom does Attitudinal Ambivalence Feel Uncomfortable." Journal of Personality and Social Psychology, vol. 82, no. 2, 2002, pp. 157-266.

McQueen, Sean. "Adapting to Language. Anthony Burgess's and Stanley Kubrick's A Clockwork Orange." Science Fiction Film and Television, vol. 5, no. 1, 2012, pp. 221-41.

McQuiston, Kate. "Value, Violence, and Music Recognized: A Clockwork Orange as Musicology." Stanley Kubrick: Essays on His Films and Legacy. Edited by Gary D. Rhodes. McFarland, 2008, pp. 105-22.

Morrison, Blake. "Introduction," A Clockwork Orange. Penguin 2002, vii-xxiv.

Phillips, Paul. A Clockwork Counterpoint. The Music and Literature of Anthony Burgess. Manchester University Press, 2010.

Rabinowitz, Peter. J. "'A Bird of Like Rarest Spun Heavenmetal'. Music in A Clockwork Orrange." Stanley Kubrick's A Clockwork Orange. Edited by Stuart Y. McDougal, Cambridge University Press, 2003, pp. 109-30.

Schabram, Kai. "'Just Music' - Anmerkungen zu Anthony Burgess' Beethoven-Rezeption in Napoleon Symphony und A Clockwork Orange." Kieler Beiträge zur Filmmusikforschung, no. 6, 2010, pp. 137-52.

Sobchak, Vivian. Screening Space. The American Science Fiction Film. Rutgers University Press, 2004. 
Schirrmacher, Beate. "Ambivalenz verspüren. Musik, Gewalt und der Körper in Elfriede Jelinek's Die Klavierspielerin und Anthony Burgess's A Clockwork Orange." Visualisierungen von Gewalt. Beiträge zu Film, Theater und Literatur. Edited by Dagmar von Hoff, Brigitte Jirku and Lena Wetenkamp. Peter Lang, 2018, pp. 125-43.

. "Sounding Words and Sticky Music. Fragmentary Lyrics and Acts of Violence." Arts of Incompletion: Fragments, Drafts, Revisions in Words and Music. Word and Music Studies 17. Edited by Axel Englund. Brill Rodopi, forthcoming.

Sorlin, Sandrine. "A Clockwork Orange: A Linguistic Symphony." Anthony Burgess: Music in Literature and Literature in Music. Edited by Marc Jeannin. Cambridge Scholars Publishing, 2009, pp. 45-56.

Wolf, Werner. The Musicalization of Fiction. A Study in the Theory and History of Intermediality. Rodopi, 1999.

Žižek, Slavoj. Violence: Six Sideways Reflections. Profile, 2009.

Beate Schirrmacher, Ph.D., senior lecturer in Comparative Literature at Linnaeus University, member of Linnaeus University Centre of Intermedial and Multimodal Studies. Ph.D. in 2012 at Stockholm University. In her doctoral thesis, Musik in der Prosa von Günter Grass, she analyses musical structures in Günter Grass's fiction, and in her postdoctoral project (2014-16) she explored The Common Ground of Music and Violence in Literature. Apart from the intermedial relationship of literature and music, her research also focuses on performative aspects of intermedial processes, and, most recently, questions of credibility and truth in mediation, as explored in her current research project Medial Representations of the Trial. 